know, he really isn't doing well." I spotted a young man behind the desk reading through a chart. "Are you a physician?" I asked, painfully aware that I was not. "Nope, OT," he replied.

And here is where the gods of medical students, or of kind old people in trouble, smiled on us. As I headed back to Mr. Knee's room, I ran into one of my very bright classmates and related to him the events of the morning as they had thus far transpired. And bless him (really, and he almost didn't graduate, for a whole bunch of political reasons), didn't he say, "Think you should get an EKG?"

An EKG! Of course. Off I went to the nursing station again, worried now that I couldn't remember whether Q waves or ST elevations would be more serious, or if flipped Ts meant anything at all. "Do you think we could get an EKG?" I asked the person I now knew to be Mr. Knee's nurse. She replied that it might be a good idea; looking at the length of my jacket, she asked, "Can you order one?" When I humbly admitted I could not, she deigned to call the doctor. Then it all got kind of busy. Having by this time forgotten that TKA meant total knee something-or-other, I now heard "EKG, twenty-five, three west" repeated over the PA system, and I slowly retreated, distanced in so many ways from the flurry of nitro sprays and oxygen and what I now know (from ACLS) to be MONA.

It really happened this way, and it always gets a laugh when I tell people, but I have ambivalent goosebumps as I write. I might have done better, sooner, more. But I guess I did something. I kept presenting my inadequate short-jacketed self at that nursing station.

And then, intensely aware of my limitations, I did a small service, I think. A CCU resident explained the situation to Mr. Knee very quickly (he'd been paged off his ward, he had work to do) and in an unpenetrable accent, and left. Displaying considerably more confidence than I felt, and not at all certain of the propriety of what I was about to do, I stepped up to the bed and asked Mr. Knee if he'd understood what he'd just been told.

"No, Doctor," he replied (and I let him), "but I feel better."
"Mr. Knee, you've had a small heartattack," I told my patient. "You're being moved to the coronary care unit now for a day or so, and they will watch you closely, and take care of you."

And as I left to meet up with my CPA group, and whichever attending I should have been presenting to, I hoped that the CCU would take care of Mr. Knee, and I didn't know whether to laugh or cry (I think I did both). And I wondered sincerely, and not for the first or last time, whether there was hope for me as a doctor.

\section{Ted St. Godard}

PGY1

Family Medical Centre

University of Manitoba

Winnipeg, Man.

\title{
The man who kept his wife in a box
}

T hat man haunts me still, even though it was twenty years ago when I met him. His wife was the patient, but I cannot recall her features. She was in an advanced stage of dementia and was suffering from bedsores. Her husband had brought her in to the community hospital where I was an intern. It's his face I remember: lined with suffering, lit up with love and concern. He had been looking after her at home for five years now, while she steadily grew worse and lost all communication with him. He told me that he had made a box for her about a year ago, because her contractures and flailings put her in danger of falling out of bed. The box kept her safe from falling, but he was apologetic that it might have made the pressure ulcers worse, despite the cotton batting he lined it with.

He had come to the emergency department because she was dying and he didn't know what else to do. There were no children. I admitted her with a sad heart and wondered how many other wives there were out there in the vast city, kept in a box, attended to by spouses who didn't know what else to do. She died within 24 hours of admission, and I was glad for her sake as well as his.

I met him again just last month. I could have sworn it was the same man the same stooped shoulders, the same patient look that comes with years of caregiving. His wife had the same list of problems: dementia, bedsores and contractures that made it difficult to find a blood pressure or administer a bath. There was the husband: sole caregiver, no children, lovingly attending to his wife just like twenty years ago. Only now the environment and context in which I was seeing them was radically different. I saw them not in the sterile environment of the hospital, but at their home, as part of a community palliative care program. And the man was not alone, but supported by personal care workers and nurses who assisted him daily in attending to his wife's needs: dressing her ulcers, adjusting her diet, bathing her. And there was no box. In its place, in the corner of the living room, was a shiny hospital bed, complete with a specialized mattress that continuously relieved the pressure on her painful ulcerated skin.

The picture was exactly the same, yet so different that I caught my breath. This time I was glad, not only for the patient, but for the medical system in which I worked that allowed such progress over twenty years. And I was especially glad for him, and for the other husbands like him, who would not have to fashion a wooden box to keep their wives in, at least not this side of the great divide of death.

\section{Beverley Smith}

Family Practice Teaching Unit

The Scarborough Hospital

Toronto, Ont. 